13. - 1974. Appendix to Evaluation of squirrel monkey (Saimiri sciureus) ranching on Santa Sofia Island, Amazonas, Colombia. Int. Zoo Yb. 14239.

14. KIRTON, K.T., 1975. Needs of the pharmaceutical industry for experimental primates. In: Primate Utilization and Conservation (G. Bermant and D. G. Lindburg, eds.), Wiley, N. Y. pp. 21-24.

15. LINDBURG, D.G. and BERMANT, G., 1975. Summary: primate conservation and utilization. In: Primate Utilization and Conservation (G. Bermant and D. G. Lindburg, eds.), Wiley, N. Y., pp. 169-181.

16. MITTERMEIER, R.A. and FLEAGLE, J.G., 1973. A primate distribution program to end wastage of sacrificed specimens. Lab. Prim. Newsl. 12 2: 1-3.

17. OTIS, L.S., 1972. Recycling primates. Lab. Prim. Newsl. 11 4: 4.

18. SOUTHWICK, C.H., SIDDIQI, M.R. and SIDDIQI, M.F., 1970. Primate populations and biomedical research. Science 170: 1051-1054.

19. SPONSEL, L.E.etal., 1974. Evaluation of squirrel monkey (Saimiri sciureus) ranching on Santa Sofia Island, Amazonas, Colombia. Int. Zoo Yb. 14: 233-240.

20. THORINGTON, R.W., Jr., 1972. The importance of nonhuman primates for man. III. Congreso Nacional de Biologia, Iquitos, Peru.

21. TSALICKIS, M., 1972. Trapping, husbandry and transport conditions of South American primates destined for research. Int. Zoo $Y$ b. 12: 23-26.

22. WARLAND, M.A.G., 1972. The status of Latin American primates. Int. Zoo Yb. 12: $16-18$.

23. WHITNEY, R.A., Jr. 1975. A domestic primate production feasibility study. In: Primate Utilization and Conservation (G. Bermant and D. G. Lindburg, eds.), Wiley, N. Y., pp. 163-167.

\title{
Increase in the Tamaraw
}

\section{W. Kuehn}

Although the tamaraw occurred on Luzon during the Pleistocene, ${ }^{1}$ in historic times this buffalo has been restricted to the Philippine island of Mindoro. There it established a reputation for aggressiveness that made it widely known in the Philippines, but it was not described for science until 1888. It has been estimated that 10,000 tamaraw Bubalus mindorensis occupied Mindoro island in $1900^{2}$ but by 1949 numbers had declined to 1000 animals, and in 1953 fewer than 250 remained. ${ }^{4}$ In 1969 Harrisson estimated that about 100 survived in three of their four known areas. Poaching was the main cause of the decline. Thanks to Harrisson's and General Lindbergh's efforts, 1969 also marked the start of the Philippine Government's tamaraw conservation effort, and wardens and guards were posted at the Mt Iglit Game Refuge and Bird Sanctuary in Occidental Mindoro. Between May 1972 and March 1974 I conducted a tamaraw study on 2000 hectares of the refuge where the major tamaraw population was to be found.

In the lower areas of Mt Iglit a mosaic of heavy cover and open grazing lands affords excellent tamaraw habitat. Cows are usually found in the preferred interspersion of forest, talahib Saccharum spontaneum grassland, and cogon Imperata cylindrica grassland, but mature bulls are intolerant of other bulls, so many adults and most juvenile bulls are forced to utilise ranges without forest cover. Large tracts of forest, offering little favoured forage, and large expanses of Themeda-Alloteropsis grassland, which are usually remote from dense cover, are little used. Mt Iglit was declared a wildlife refuge in 1961 but ranching had continued on the study area until 1969, and the tamaraw dwindled to about 20 animals. ${ }^{3}$ Once guards had been installed poaching by outsiders stopped. Members of the Batangan tribe continue a small amount of hunting with spear traps and fires but this appears to have 